\title{
Stability study of azithromycin in ophthalmic preparations
}

\author{
Andréia de Haro Moreno, Maria Fernanda Conz da Silva, Hérida Regina Nunes Salgado*
}

Department of Drugs and Medicines, School of Pharmaceutical Sciences, University of São Paulo State

\begin{abstract}
A stability study of azithromycin in ophthalmic preparations was developed by submission to different types of light, temperature and $\mathrm{pH}$, using the biodiffusion assay (cylinder 3 x 3 ) for the quantifications. Bacillus subtilis, ATCC 9372, was used as test organism. The used concentration range was of 50 to $200 \mu \mathrm{g} / \mathrm{mL}$. The study demonstrated that the drug suffered degradation when submitted to the ultraviolet light, germicide light, solar luminosity, acid solution, basic solution and hydrogen peroxide solution. The results were analyzed by the analysis of variance (ANOVA).
\end{abstract}

Uniterms: Azithromycin/stability study. Bioassay. Photodegradation. Ophthalmic preparations.

O estudo de estabilidade de azitromicina em preparações oftálmicas foi realizado após exposição a diferentes tipos de luz, temperatura e pH, utilizando o método de difusão em ágar (cilindros 3 x 3) para as quantificações. A faixa de concentração foi de 50 a $200 \mu \mathrm{g} / \mathrm{mL}$. O estudo demonstrou que o fármaco sofreu degradação quando submetido às luzes ultravioleta, germicida e solar, e a soluções ácida, alcalina e de peróxido de hidrogênio. Os resultados foram analisados através da análise da variância (ANOVA).

Unitermos: Azitromicina/estudo de estabilidade. Bioensaio. Fotodegradação. Preparações oftálmicas.

\section{INTRODUCTION}

Stability is defined as the capacity of a drug substance or drug product to remain within established specifications to maintain its identity, strength, quality, and purity throughout the retest or expiration dating periods (Brasil, 2005; Nudelman, 1975; Yoshida, Sato, Moroi, 1993). Due to their possible composition, pharmaceuticals are especially sensitive to environmental factors. Strict storage conditions are necessary for the maintenance of integrity and product activity (Waterman, Adami, 2005).

Stability test of an active substance or finished product provides evidence on the drug quality and its variation with the time, influenced by a variety of environmental factors such as temperature, humidity and light (Tonnesen, 2001). The Brazilian stability studies guidelines were published at the document RE $n^{\circ} 1$, on July $1^{\text {st }}, 2005$, which determined the specifications for this specific analysis (Brasil, 2005).

The azithromycin (Figure 1), is 1-oxa-6-azacyclo-

\footnotetext{
*Correspondence: H. R. N. Salgado. Department of Drugs and Medicines, Faculty of Pharmaceutical Sciences, University of the State of São Paulo UNESP. Rod. Araraquara-Jaú, km 1 - 14801-902 - Araraquara - SP, Brazil. E-mail: salgadoh@fcfar.unesp.br
}

pentadecan-15-one, 13-[(2,6-dideoxy-3-C-methyl-3- $O$ -methyl- $\alpha$-L-ribo-hexopyranosyl)oxy]-2-ethyl-3,4,10trihydroxy-3,5,6,8,0,12,14-heptamethyl-11-[3,4,6-trideoxy-3-(dimethylamino)- $\beta$-D-xylo-hexopyranosyl)oxy], dihydrate, is an azalide, a subclass of macrolide antibiotics. The macrocyclical lactone expansion and the presence of nitrogen atom in the lactone ring are responsible for the best pharmacological and microbiological azithromycin characteristics. Azithromycin has similar antimicrobial spectrum as erythromycin, but is more effective against certain gram-negative bacteria, particularly Haemophilus influenzae.

Azithromycin prevents bacteria from growing by interfering with their protein synthesis. Azithromycin binds to the $50 \mathrm{~S}$ subunit of the bacterial ribosome, and thus inhibits translation of mRNA. Nucleic acid synthesis is not affected (Korolkovas, 2000; United States Pharmacopeia, 2005; Zanini et al., 1998).

Azithromycin is commercialized by Brazilian pharmacies as ophthalmic solution, with concentration of $1.667 \mathrm{mg} / \mathrm{mL}$ in physiological buffered vehicle (Zanini et al., 1998).

For many aqueous drug solutions, stress conditions such as $\mathrm{pH}$, temperature, light and oxidizing atmosphere 


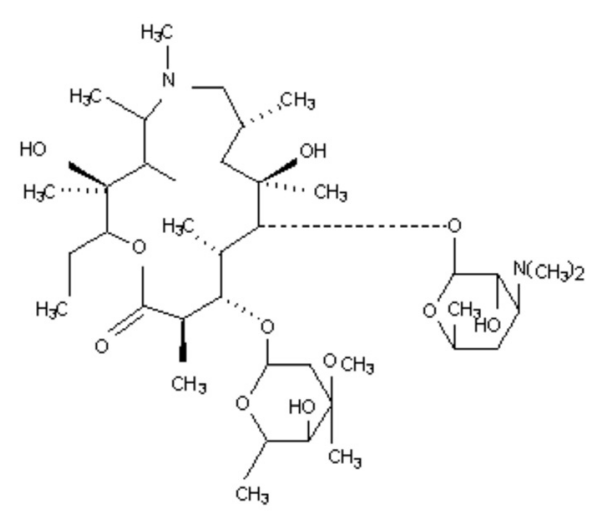

FIGURE 1 - Chemical structure of the azithromycin $\left(\mathrm{C}_{36} \mathrm{H}_{72} \mathrm{~N}_{2} \mathrm{O}_{12}\right.$. $\mathrm{H}_{2} \mathrm{O} ; M_{\mathrm{r}}$ 785.02; CAS 83905-01-5).

can sometimes affect the maximum stability of the drug (Kommanaboyina, Rhodes, 1999). For this reason, the aim of the study was to evaluate the stability of azithromycin in ophthalmic solutions face to several stress conditions, such as temperature, light and acid, alkaline and hydrogen peroxide solutions.

\section{MATERIAL AND METHODS}

\section{Material}

Azithromycin reference substance was gently supplied by the Ariston Laboratory (São Paulo, Brazil). Azithromycin raw material and ophthalmic solutions were gently supplied by the Bandeirantes Pharmacy (Araraquara, Brazil). Azithromycin ophthalmic solutions were claimed to contain $1.667 \mathrm{mg} / \mathrm{mL}$ (as anhydrous base) of the drug. All used chemicals were of analytical grade.

\section{Preparation of azithromycin reference substance}

The standard and sample stock solutions were prepared by dissolution in water $(100 \mathrm{mg}$ in a $50 \mathrm{~mL}$ volumetric flask) and then diluted with potassium phosphate buffer solution $\mathrm{pH} 8.0$ and sonicated by $10 \mathrm{~min}(2000 \mu \mathrm{g} / \mathrm{mL})$. Standard solutions were freshly prepared in the concentrations of $50.0,100.0$ and $200.0 \mu \mathrm{g} / \mathrm{mL}$ by transferring aliquots of $250.0,500.0$ and $1000 \mu \mathrm{L}$, respectively, of the stock solution to $10 \mathrm{~mL}$ volumetric flasks and diluting to volume with potassium phosphate buffer solution $\mathrm{pH}$ 8.0.

\section{Potassium phosphate buffer solution}

Amounts of $16.73 \mathrm{~g}$ of dipotassium hydrogen phosphate and $0.52 \mathrm{~g}$ of potassium dihydrogen phosphate were dissolved in $1000 \mathrm{~mL}$ of distilled water $(\mathrm{pH}=8.0)$.

\section{Preparation of the azithromycin solutions}

A commercial ophthalmic solution composed by azithromycin $25.0 \mathrm{mg}$ in $15.0 \mathrm{~mL}$ of physiological solution with concentration of $1.667 \mathrm{mg} / \mathrm{mL}$ was used to prepare the sample solutions: $3.0 \mathrm{~mL}, 6.0 \mathrm{~mL}$, and $12.0 \mathrm{~mL}$ of azithromycin commercial ophthalmic solution (10 samples) were transferred to a $100 \mathrm{~mL}$ volumetric flask and diluted to volume with potassium phosphate buffer solution $\mathrm{pH} 8.0$, to give final concentrations of 50.0, 100.0 and $200.0 \mu \mathrm{g} / \mathrm{mL}$, respectively.

\section{Organism and inoculum}

The quantitative measurement of the azithromycin was carried out through diffusion in a test-agar using Bacillus subtilis ATCC 9372 as indicator microorganism. The cultures of B. subtilis ATCC 9372 were stored on Grove-Randall number 1 agar (Merck, Brazil) at freezer and pealed to another Grove Randall number 1 agar $(24 \mathrm{~h}$ before assay) that was kept at $37^{\circ} \mathrm{C}$. The bacteria were suspended in brain heart infusion broth (Merck, Brazil) using a glass homogenizer. Diluted culture suspensions of $25 \% \pm$ $2 \%$ turbidity were obtained at $580 \mathrm{~nm}$ (Farmacopéia Brasileira, 1988), using a suitable spectrophotometer (Merck SQ118, Germany) and a $10 \mathrm{~mm}$ diameter test tube as an absorption cell against brain heart infusion broth as blank.

\section{Biodiffusion assay}

The agar was composed of 2 separate layers, and only the upper layer was inoculated. The Grove-Randall number 11 agar $(20 \mathrm{~mL})$ was poured into microbiological petri dish $(100 \mathrm{~mm}$ x $20 \mathrm{~mm})$ for the base layer. After solidification, the inoculum $(5.0 \mathrm{~mL})$ was distributed to the surface of each base layer. Six stainless steel cylinders of uniform size ( $8 \mathrm{~mm} \times 6 \mathrm{~mm} \times 10 \mathrm{~mm}$ ) were placed on the surface of inoculated agar and an exactly measured volume $(200 \mu \mathrm{L})$ of the corresponding dilution was deposited into each cylinder. Three alternated cylinders were filled with $200 \mu \mathrm{L}$ of reference substance and sample solutions. In this way, each dish contained three cylinders with three different azithromycin reference substance dilution and three cylinders with the corresponding sample concentrations. The bioassay plates were aerobically incubated at $35^{\circ} \mathrm{C} \pm$ $2{ }^{\circ} \mathrm{C}$ for $18 \mathrm{~h}$. The diameter (in $\mathrm{mm}$ ) of growth inhibition zones was carefully measured using a caliper (Mitutoyo, Japan) with a precision of at least $0.1 \mathrm{~mm}$. Six plates were used in each assay as shown in Figure 2.

The percentage activity of azithromycin in ophthalmic solutions was calculated by Hewitt equations 
(Hewitt, 1977). The assay was statistically calculated by linear parallel model and by means of regression analysis, being then verified using analysis of variance (ANOVA).

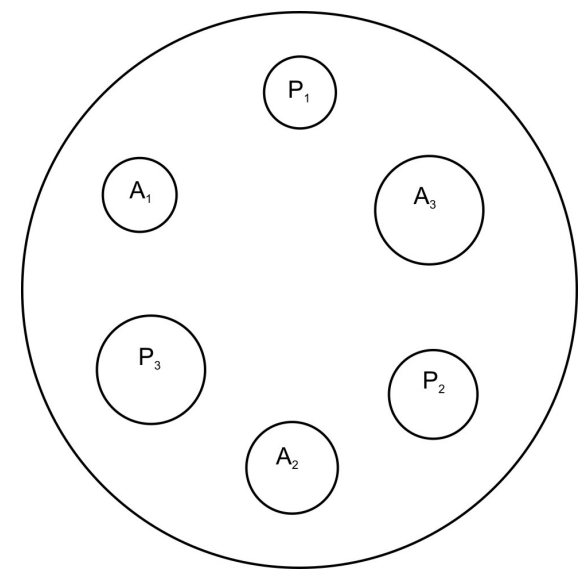

FIGURE 2 - Delineation 3 x 3, demonstrating the standard solutions (P) and sample solutions (A) disposed in Petri dishes, where $\mathrm{P}_{1}(50.0 \mu \mathrm{g} / \mathrm{mL}) ; \mathrm{P}_{2}(100.0 \mu \mathrm{g} / \mathrm{mL}) ; \mathrm{P}_{3}(200.0 \mu \mathrm{g} / \mathrm{mL})$ and $\mathrm{A}_{1}(50.0 \mu \mathrm{g} / \mathrm{mL}) ; \mathrm{A}_{2}(100.0 \mu \mathrm{g} / \mathrm{mL}) ; \mathrm{A}_{3}(200.0 \mu \mathrm{g} / \mathrm{mL})$.

\section{Azithromycin degradation tests}

Sample solutions (50.0, 100.0 and $200.0 \mu \mathrm{g} / \mathrm{mL}$ ) prepared for the biodiffusion assay were stored in glass bottles closed and submitted the following expositions: temperature $\left(50\right.$ and $100^{\circ} \mathrm{C}$ per 20 and 60 days); ultraviolet light $284 \mathrm{~nm}(10 \mathrm{~cm}$ from the source for 1, 2, 7, 14, 21 and 28 days); solar light (for 2, 5, 7 and 10 days); ultraviolet germicide light $254 \mathrm{~nm}(10 \mathrm{~cm}$ from the source for 2, 6, 12, $24,36,48$ and 72 hours). The lamps used in the test were UV Lamp SM808 (Zheijang, China) and UV Germicidal Lamp (Zheijiang, China).

Portions of $10 \mathrm{~mL}$ of the ophthalmic solutions $(1.667 \mu \mathrm{g} / \mathrm{mL})$ were transferred to three flasks in order to develop the chemical degradation study with $0.1 \mathrm{~mol} / \mathrm{L}$ hydrochloric acid, $0.1 \mathrm{~mol} / \mathrm{L}$ sodium hydroxide and $0.3 \%(\mathrm{v} / \mathrm{v})$ hydrogen peroxide solutions:

\section{Acid degradation}

$5.0 \mathrm{ml}$ of $0.1 \mathrm{~mol} / \mathrm{L}$ hydrochloric acid solution was added to the ophthalmic solution $(1.667 \mu \mathrm{g} / \mathrm{mL})$. The solution was warmed in a bath at $70{ }^{\circ} \mathrm{C}, \pm 2{ }^{\circ} \mathrm{C}$, during 6 hours, cooled and neutralized with $5.0 \mathrm{~mL}$ of $0.1 \mathrm{~mol} / \mathrm{L}$ sodium hydroxide solution. Portions of 1.5, 3.0 and $6.0 \mathrm{~mL}$ were transferred to $25 \mathrm{~mL}$ volumetric flasks and diluted to volume with purified water to give final concentrations of $50.0,100.0$ and $200.0 \mu \mathrm{g} / \mathrm{mL}$, respectively.

\section{Alkaline degradation}

$5.0 \mathrm{ml}$ of $0.1 \mathrm{~mol} / \mathrm{L}$ sodium hydroxide solution was added to the ophthalmic solution $(1.667 \mu \mathrm{g} / \mathrm{mL})$. The solution was warmed in a bath at $70{ }^{\circ} \mathrm{C}, \pm 2{ }^{\circ} \mathrm{C}$, during 6 hours, cooled and neutralized with $5.0 \mathrm{~mL}$ of $0.1 \mathrm{~mol} / \mathrm{L}$ hydrochloric acid solution. Portions of $1.5,3.0$ and $6.0 \mathrm{~mL}$ were transferred to $25 \mathrm{~mL}$ volumetric flasks and diluted to volume with purified water to give final concentrations of $50.0,100.0$ and $200.0 \mu \mathrm{g} / \mathrm{mL}$, respectively.

\section{Degradation with hydrogen peroxide}

$5.0 \mathrm{~mL}$ of $0.3 \%(\mathrm{v} / \mathrm{v})$ hydrogen peroxide solution was added to the ophthalmic solution $(1.667 \mu \mathrm{g} / \mathrm{mL})$. The solution was warmed in a bath at $70{ }^{\circ} \mathrm{C} \pm 2{ }^{\circ} \mathrm{C}$, during 6 hours, cooled and added $5.0 \mathrm{~mL}$ of purified water. Portions of 1.5, 3.0 and $6.0 \mathrm{~mL}$ were transferred to $25 \mathrm{~mL}$ volumetric flasks and diluted to volume with purified water to give final concentrations of 50.0, 100.0 and $200.0 \mu \mathrm{g} / \mathrm{mL}$, respectively.

After the sample expositions, the assays for drug quantification were developed by biodiffusion assay (Salgado, Roncari, 2005) and the potency calculated by Hewitt equations (Hewitt, 1977). The assay was statistically calculated by linear parallel model and regression analysis using analysis of variance (ANOVA) (AOAC, 1990).

\section{RESULTS AND DISCUSSION}

Pharmaceutical products quality is of vital importance for patient safety. The presence of impurities may influence the efficacy and safety of pharmaceuticals. Impurities and potential degradation products can cause changing of chemical, pharmacological and toxicological properties of drugs, having significant impact on product quality and safety (Tonnesen, 2001). Stability studies of pharmaceutical preparations become necessary, to assure product purity, safety, potency and effectiveness until use (Nudelman, 1975).

Stress studies are said to be useful to determine if accidental exposures to conditions other than those proposed have been deleterious to product; in order to evaluate which specific test parameters would be the best indicators of product stability; and to reveal the degradation patterns. Stress conditions are also mentioned in literature on establishment of stability-indicating assays. The total information was tabulated for different types of activities, such as hydrolysis in acid, alkaline and neutral conditions, oxidation and photolysis (ICH, 1996).

According to ICH (1996), the most used stress 
conditions for decomposition study in acid medium were based on hydrochloric acid at strength of $0.1 \mathrm{~mol} / \mathrm{L}$. The temperature range varied from $40{ }^{\circ} \mathrm{C}$ up to $110^{\circ} \mathrm{C}$, and drugs were kept under temperature conditions for periods ranging from few minutes up to 2 months.

The stress conditions used for the hydrolysis of drugs under alkaline conditions run in parallel to those used for acid conditions. Sodium hydroxide is most used, at strength of $0.1 \mathrm{~mol} / \mathrm{L}$. Just like acidic degradation, a lot of variation is observed respecting time and exposure temperature of drugs to alkali.

The hydrogen peroxide seems to be much more popular for the purpose than any other oxidizing agents. The used strength of hydrogen peroxide varies between $1 \%$ to $30 \%$. In some drugs, extensive degradation is seen when exposed to $3 \%$ hydrogen peroxide, for very short time periods, at room temperature. These conditions are not expected to show any change, even in the presence of high dose of oxidizing agents. The drug may be declared to be "practically stable" if no products are formed on subjecting the drug to this condition.

Light exposure can induce chemical degradation in susceptible molecules and the most obvious result of drug photodecomposition is the product loss of potency (Tonnesen, 2001). Mostly, drugs are exposed to short/

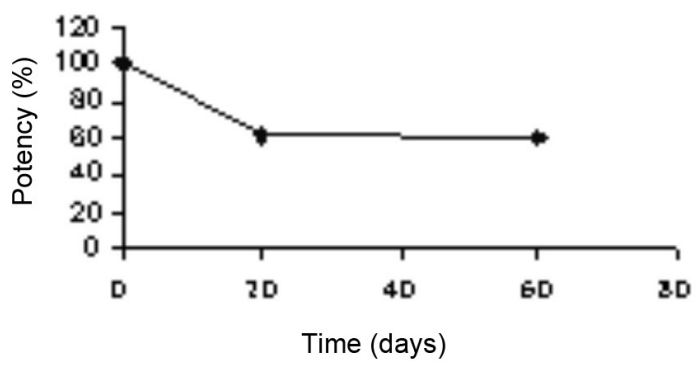

A

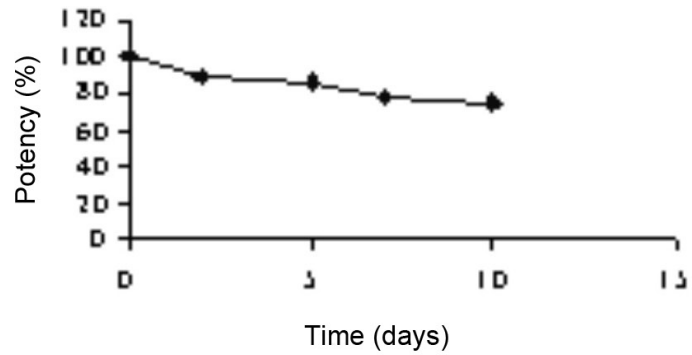

long wavelength UV light, or fluorescent light of varying illumination. Efforts are usually made to maintain the temperature around room temperature. The period of exposure ranges from a few hours to several months, depending on the light source intensity. Like oxidation, based on whether a drug is photolytic or not, varied types of decomposition behaviors are seen. Photolability studies are done on drugs in either solid or solution forms (ICH, 1996).

The sample solutions presented loss of the drug potency after the stress expositions, according to Table I. The ultraviolet light $(284 \mathrm{~nm})$ showed considerable potency loss (18.86\%) after 28 days when compared with other exposition types, such as temperature, ultraviolet germicide light (254 $\mathrm{nm}$ ) and solar light. However, the chemical degradation by acid, alkali and hydrogen peroxide presented almost total potency loss of the drug (11.5\%), indicating drug susceptibility for direct degradation. No interference from the sample excipients and vehicles could be observed under experimental conditions.

The biodiffusion assay can reveal subtle changes not demonstrated by chemical methods, such as chemical degradation, and allows evaluation of azithromycin potency (Andrews, 1999; Breier et al., 2002; Turcinov, Pepeljnjak, 1998). Figure 3 represents the drug potency decline after different types of expositions: temperature

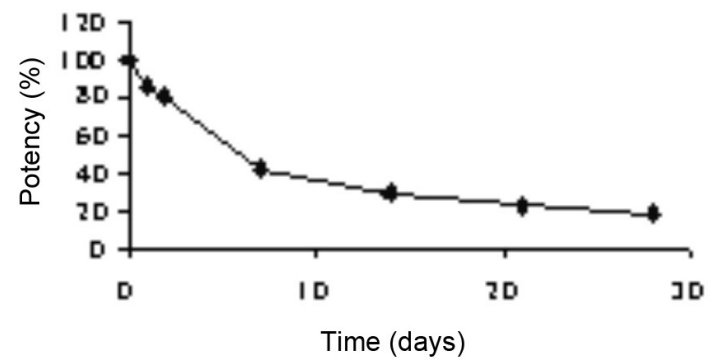

B

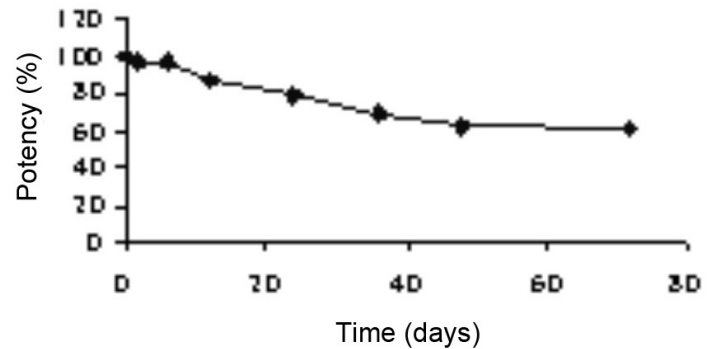

FIGURE 3 - Azithromycin potency decline after different types of expositions: temperature $50{ }^{\circ} \mathrm{C}$ (A); ultraviolet light (B); solar light (C); ultraviolet germicide light (D). 
$50^{\circ} \mathrm{C}(\mathrm{A})$; ultraviolet light (B); solar light (C); ultraviolet germicide light (D).

According to the Figure 3 the loss of potency was considerable when the samples were exposed to temperature (A) and ultraviolet light (B), showing the product susceptibility to light and thermal degradation.

The inhibition zones of azithromycin without degradation are represented in Figure 4, and the Figures 5, 6, 7 and 8 showed the zone diameters for the azithromycin under chemical degradation (acid, alkaline and hydrogen peroxide solutions), UV light (284 nm), UV germicide light (254 nm) and solar light, respectively.

There were clear reduction of zone diameters, specially for the azithromycin under chemical degradation, when compared with the inhibition zone at zero time (product not degraded) (Figures 4 and 5). The Figures 6, 7 and 8 showed the photodegradation of azithromycin. According to figures, the UV light $(284 \mathrm{~nm})$ exposition was more deleterious than UV germicide light (254 nm) and solar light expositions. Biological products such as antibiotics are particularly sensitive to stress conditions.

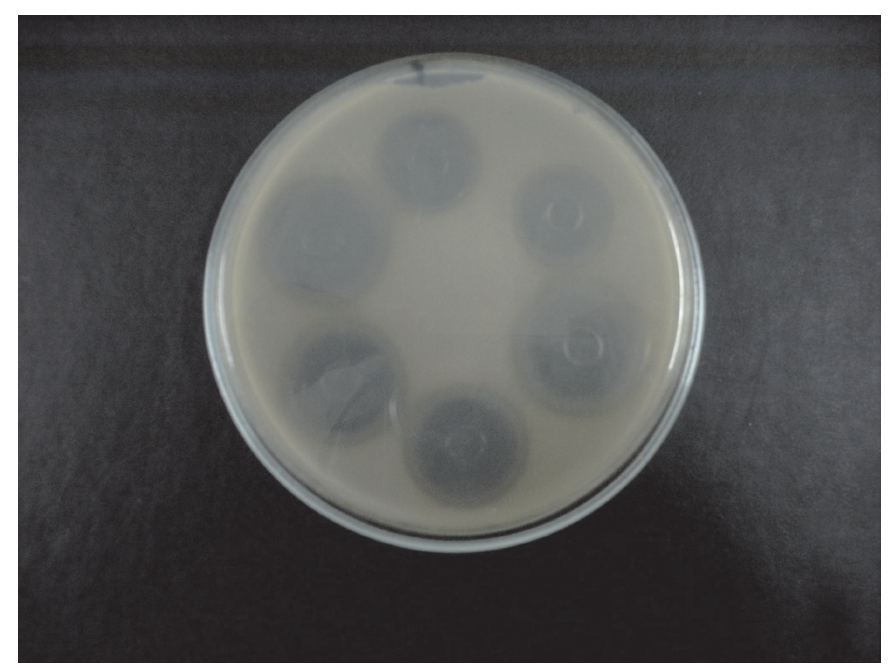

FIGURE 4 - Zone diameters for the azithromycin at zero time.
Their main routes of decomposition can also vary, depending on the used chemical agents.

Segregation and quantification of antibiotic components by chemical methods such as HPLC, although precise, may not provide a true indication of their biological activity, and attempts to correlate antibiotic bioassay results with those from chemical methods have been usually disappointing. So, these results demonstrate that bioassays continue to play an essential role in the manufacture and quality control of antibiotic medicines.

The biodiffusion assay used for the azithromycin quantification was validated by Salgado and Roncari (2005). The statistical analysis demonstrated the applicability of the method: there were no deviations from parallelism and linearity with results obtained $(P<0.05)$. Table I shows the results obtained for azithromycin determinations after the stress expositions.

The stability study has as main goals to explore the nature, kinetic course and degradation of drugs, as well as determining for how much time products can conserve their original constitution (Marona, Zuanazzi, Schapoval, 1999; Marona, Schapoval, 2001). Quality control in the pharmaceutical industry is very important to assure effectiveness and confirm the quality of the medicines being commercialized for the population.

\section{CONCLUSIONS}

In this study, we concluded that it is necessary to be worried about the form, place and storage time of drugs, so that degradation reaction could be avoided: $\mathrm{pH}$ must be controlled, avoiding extreme values, as the chemical degradation presented almost total loss of drug potency; and light expositions showed considerable loss of drug potency as well. These procedures can avoid the drug degradation and the consequent product loss of effectiveness and security. These studies are important to establish the type and adequate places for storage of pharmaceutical

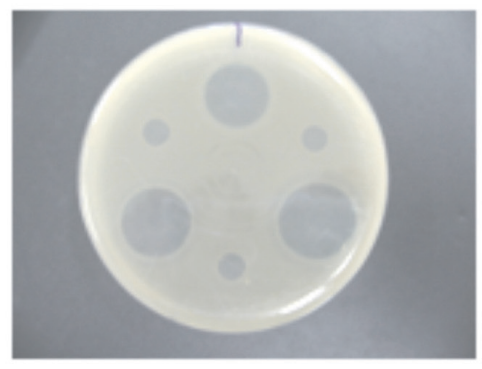

$\mathrm{HCl}$ degradation

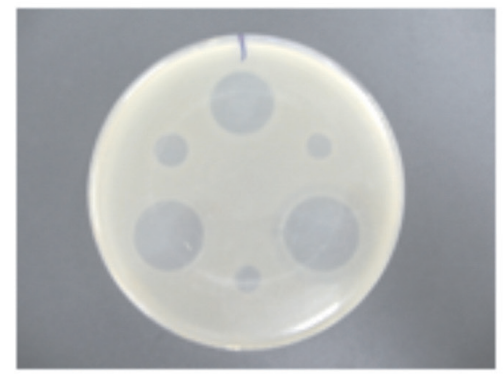

$\mathrm{NaOH}$ degradation

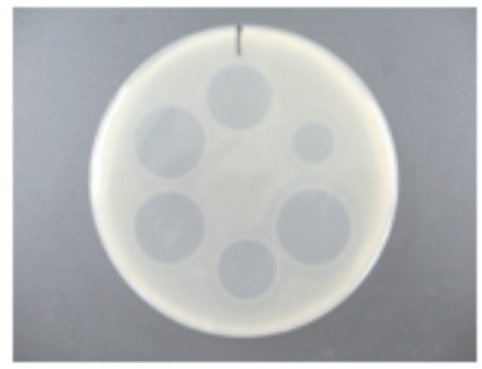

$\mathrm{H}_{2} \mathrm{O}_{2}$ degradation

FIGURE 5 - Zone diameters for the azithromycin under different chemical conditions of degradation studies (acid, alkaline and hydrogen peroxide solutions). 


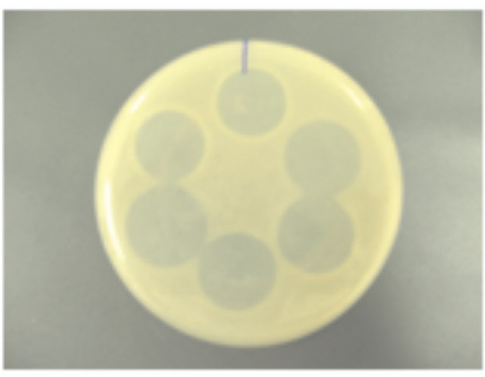

1 day
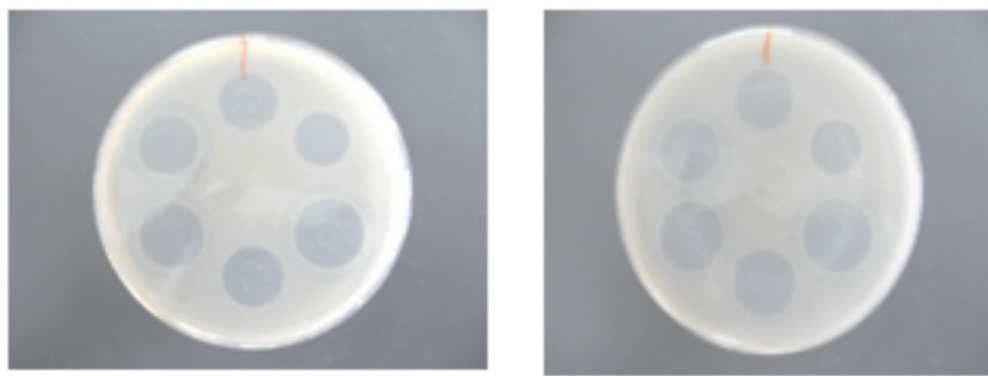

21 days

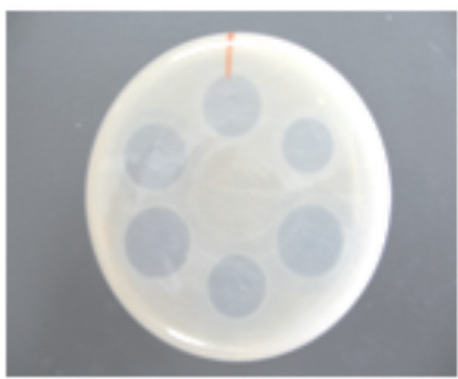

7 days

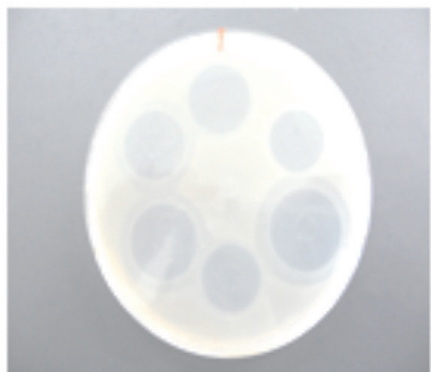

28 days

FIGURE 6 - Zone diameters for the azithromycin under UV light (284 nm) exposition.

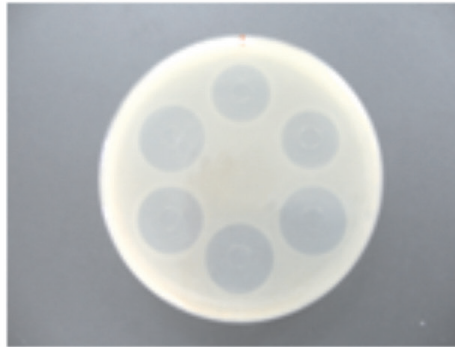

6 hours

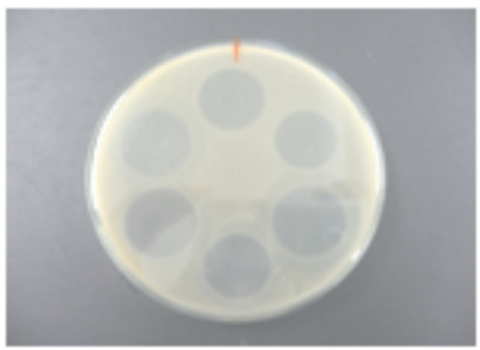

36 hours

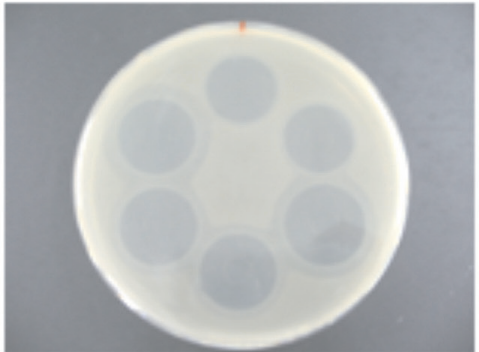

12 hours

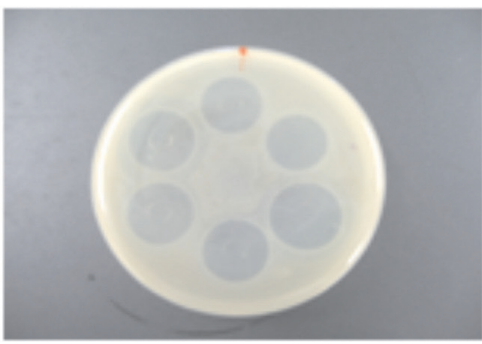

48 hours

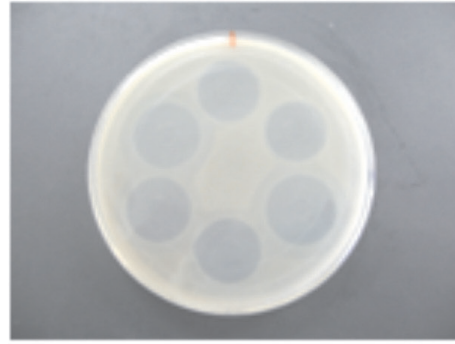

24 hours

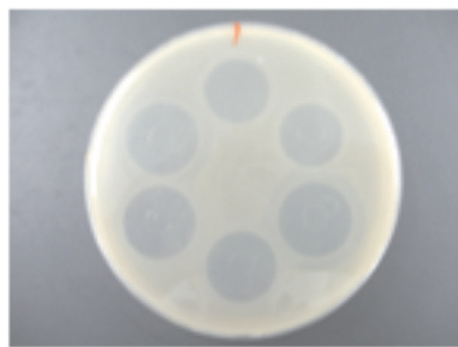

72 hours

FIGURE 7 - Zone diameters for the azithromycin under UV germicide light (254 nm) exposition. 
TABLE I - Experimental values obtained for the determination of azithromycin by the biodiffusion assay after stress expositions

\begin{tabular}{lccc}
\hline Exposition & Period & Potency $\mathbf{( \% )}$ & CV (\%) \\
\hline Temperature $50^{\circ} \mathrm{C}$ & 20 days & 61.17 & 0.89 \\
Temperature $50^{\circ} \mathrm{C}$ & 60 days & 59.90 & 0.73 \\
Temperature $100^{\circ} \mathrm{C}$ & 20 days & total powder loss & - \\
Ultraviolet light & 1 day & 85.39 & 1.56 \\
$(284 \mathrm{~nm})$ & 2 days & 80.85 & 0.54 \\
& 7 days & 42.88 & 0.45 \\
& 14 days & 29.57 & 0.76 \\
& 21 days & 23.49 & 0.51 \\
& 28 days & 18.86 & 0.88 \\
Ultraviolet germicide & 2 hours & 96.93 & 0.61 \\
light $(254$ nm) & 6 hours & 96.87 & 0.50 \\
& 12 hours & 87.35 & 1.19 \\
& 24 hours & 78.70 & 0.63 \\
& 36 hours & 69.43 & 0.38 \\
Solar light & 48 hours & 62.24 & 1.15 \\
& 72 hours & 60.02 & 0.89 \\
& 2 days & 89.27 & 0.77 \\
Acid degradation & 5 days & 86.14 & 0.83 \\
Alkaline degradation & 7 days & 77.70 & 0.49 \\
Hydrogen peroxide degradation & 10 days & 74.25 & 0.65 \\
\hline
\end{tabular}

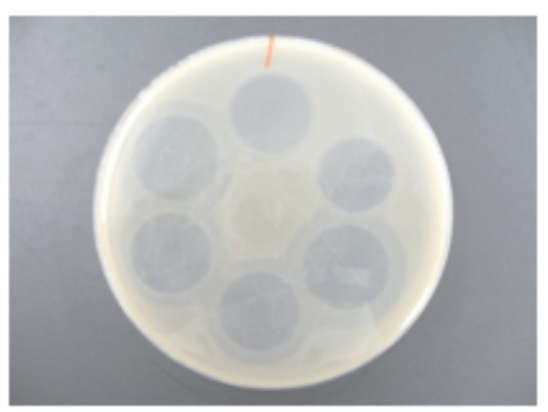

2 days

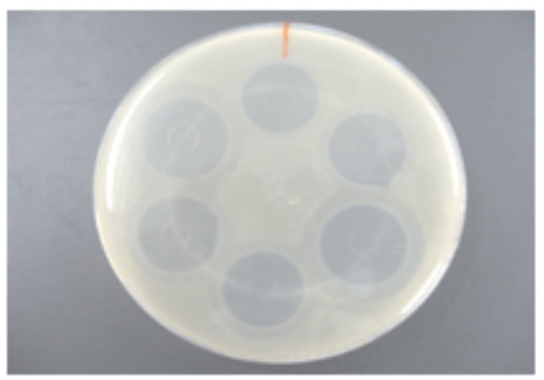

7 days

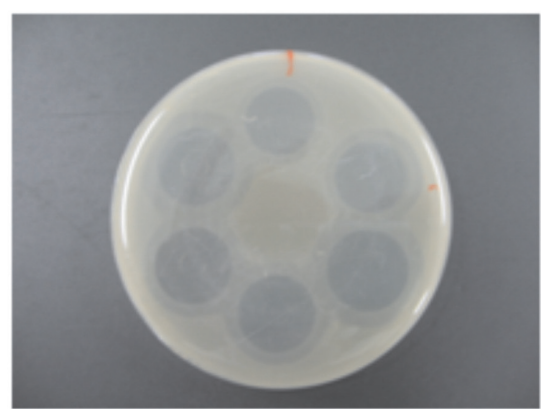

5 days

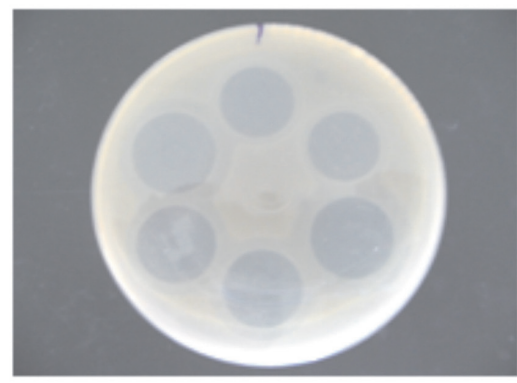

10 days

FIGURE 8 - Zone diameters for the azithromycin under solar light exposition. 
preparations, in order to prevent the degradation after expositions, assuring the drug integrity, and product quality and safety for the user.

\section{ACKNOWLEDGEMENTS}

The authors are grateful to Mrs Maria de Fátima Rodrigues for her technical support; Ariston Indústrias Químicas e Farmacêuticas Ltda. for providing azithromycin reference substance; and PharmD Jeferson Yashuda, of Farmácia Bandeirantes (Araraquara, Brazil), for providing the azithromycin raw material and ophthalmic solutions. This work was supported by CNPq-Brazil program and PADC-FCF-UNESP.

\section{REFERENCES}

ANDREWS, J. M. Microbiological assays. In: REEVES D. S.; WISE R.; ANDREWS J. M.; WHITE L. O. Clinical antimicrobial assays. Oxford: Oxford University, 1999. p. 35-44.

AOAC. Association of Official Analytical Chemists. Official methods of analysis. 15.ed. Arlington, 1990. v.1, p.xvii.

BRASIL. Agência Nacional de Vigilância Sanitária (ANVISA), Resolução RE $n^{\circ} 1$, de 29 de Julho de 2005, que apresenta um guia para a Realização de Estudos de Estabilidade. Available at: http://www.anvisa.gov.br/medicamentos/ banco-med.htm. Access on: 25 out. 2007.

BREIER, A. R.; GARCIA, C. V.; OPPE, T. P.; STEPPE, M.; SCHAPOVAL, E. E. S. Microbiological assay for azithromycin in pharmaceutical formulations. J. Pharm. Biomed. Anal., v.29, p.957-961, 2002.

FARMACOPÉIA BRASILEIRA. 4.ed. São Paulo: Atheneu, 1988. pt 1, p.v.5.2.17.

HEWITT, W. Microbiological assay. An introduction to quantitative principles and evaluation. New York: Academic Press, 1977. p.41-42.

ICH. International Conference on Harmonization of technical Requirements for registration of Pharaceutical for human Use: Guideline on validation of Analytical Procedure: Methodology, 1996.
KOMMANABOYINA, B.; RHODES, C. T. Trends in stability testing, with emphasis on stability during distribution and storage. Drug Develop. Ind. Pharm., v.25, p.857-868, 1999.

KOROLKOVAS, A. Dicionário Terapêutico Guanabara. 6.ed. Rio de Janeiro: Guanabara Koogan, 1999/2000. p.159.

MARONA, H. R. N.; ZUANAZZI, J. A. S.; SCHAPOVAL, E. E. S. High-performance liquid chromatographic assay of sparfloxacin and its degradation products. J. Antimicrob. Chemother., v.44, p.301-302, 1999.

MARONA, H. R. N.; SCHAPOVAL, E. E. S. Analysis of sparfloxacin and its degradation products by bioassay. Acta Pharm. Turcica, v.43, p.7-9, 2001.

NUDELMAN, N. E. E. Estabilidad de medicamentos. Buenos Aires: El Ateneo, 1975. p.98-125.

SALGADO, H. R. N.; RONCARI, A.F.F. Microbiological assay for determination of azithromycin in ophthalmic solutions. Acta Pharm. Sinica, v.40, p.544-549, 2005.

TONNENSEN, H. H. Formulation and stability testing of photolabile drugs. Int. J. Pharm., v.225, p.1-14, 2001.

TURCINOV, T.; PEPELJNJAK, S. Azithromycin potency determination: Optimal conditions for microbiological diffusion method assay. J. Pharm. Biomed. Anal., v.17, p.903-910, 1998.

UNITED STATES PHARMACOPEIA. 28.ed. Rockville: The United States Pharmacopeial Convention, 2005. p.150-155.

YOSHIDA, Y.; SATO, E.; MOROI, R. Photodegradation products of levofloxacin in aqueous solution. Arzn. Forsch. Drug Res., v.43, p.601-606, 1993.

WATERMAN, K. C.; ADAMI, R. C. Accelerated aging: predictions of chemical stability of pharmaceuticals. Int. J. Pharm., v.293, p.101-125, 2005.

ZANINI, A. C.; BASILE, A. C.; FOLLADOR, W., OGA, S. Guia de Medicamento. 2.ed. São Roque: Ipex, 1997/1998. p.180-182.

Received for publication on $31^{\text {th }}$ march 2008 Accepted for publication on $26^{\text {th }}$ november 2008 